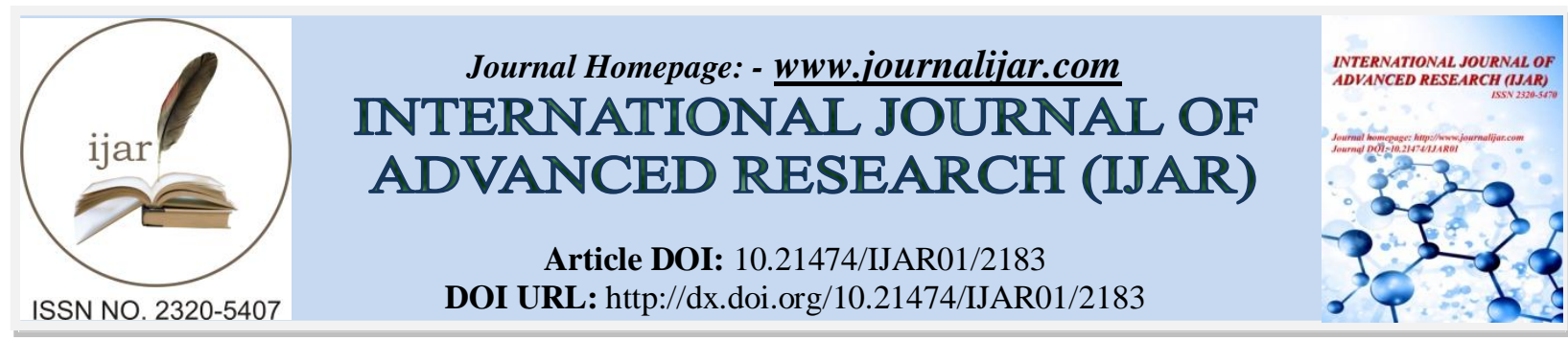

RESEARCH ARTICLE

\title{
HYDROCHEMICAL QUALITY OF SPRINGS IN MAHOUNA MASSIF, GUELMA, NORTH-EAST OF ALGERIA.
}

\author{
"Nouar Tahar, Toumi abdelouheb, Gueroui Yassine, Abesse and Harida Bouchera. \\ Civil Engineering and Hydraulic Laboratory, PO Box 401, University 8 mai 1945, Guelma, 24000. Algeria.
}

\section{Manuscript Info}

Manuscript History

Received: 27 September 2016

Final Accepted: 30 October 2016

Published: November 2016

Key words:-

Hydrochemistry, springs, quality, Guelma, Algeria

\section{Abstrac}

The hydrochemistry of springs in Mahouna massif, located at Guelma , north east of Algeria was evaluated for drinking water and irrigation. Ten major springs were sampled. The physical parameters $(\mathrm{pH})$, Electric Conductivity (EC), Total Dissolved Solids (TDS), TH as well as the concentrations in major ions $\mathrm{Ca}^{2+}, \mathrm{Mg}^{2+}, \mathrm{Na}^{+}, \mathrm{K}^{+}, \mathrm{Cl}{ }^{-}, \mathrm{SO}_{4}{ }^{2-}$, $\mathrm{HCO}_{3}^{-}, \mathrm{Fe}^{2+}$ and $\mathrm{NO}_{3}^{-}$analyzed by standard methods. Two chemical facies are predominant in the study area $\left(\mathrm{Na}-\mathrm{Cl}\right.$ and $\left.\mathrm{Ca}+\mathrm{Mg}-\mathrm{HCO}_{3}\right)$. Water-rock interaction characterized by the dissolution of carbonates and silicates plays a primordial role in the chemical composition of the groundwater. The hydrochemical study of the area showed that the majority of cations and anions, electric conductivity, the TDS and the $\mathrm{TH}$ which characterize the chemical composition of the water springs are above the limits allowed for the drinking water according to standards. SAR, SS ${ }^{*}$ and RSC reveal that, barring a few locations, most of the groundwater samples are safe for irrigation purposes.

Copy Right, IJAR, 2016,. All rights reserved.

\section{Introduction:-}

In the study area, Water resources have become increasingly limited and difficult to exploit by water resources have become increasingly limited, difficult to exploit by drilling because of the rugged terrain and shows the very steep slopes. Springs are natural emergence that appear to the surface. They are natural drainage or one-off outlets of groundwater. In the worldwide, the emergences are captured to satisfy for water supply (Bourlier et al., 2005; Karakaya, 2006; Omar, 2008). In the Massif of Mahouna located south of Guelma, natural springs are the main points of access to water resources for rural populations. These sources are sustainable and water flow is between 2 to $101 / \mathrm{s}$. From a hydro geological point of view, they represent a potential supply of drinking water to populations and meet the demand for irrigation water and livestock. The purpose is to evaluate the present status of water quality in the area for human consumption and irrigation uses

\section{Material and Methods:-}

Study area:-

The study area is belonging to Guelma district and located in the north-eastern part of Algeria (Fig. 1). Many springs emerge in this locality and its water contributes in drinking purposes and irrigation of the communities and farmers of the area. The study area is characterized by an elevation of about 755 to $1110 \mathrm{~m}$ above the sea. The 
outcrops are occupied by the mastic, cork oak, blueberry, myrtle and olives trees. The most important economic activity of the area is agriculture. The climate of the study area is considered to be semi tempered, the annual average precipitation being approximately $555 \mathrm{~mm}$. Rainfall occurs from august to June, with a maximum during January and February of each year. The average temperature is approximatively $9^{\circ} \mathrm{C}$ in winter and $27^{\circ} \mathrm{C}$ in summer, though summer high temperature can reach $35^{\circ} \mathrm{C}$ in July. Annual total evaporation rises to $919.43 \mathrm{~mm}$. Geologically, the surface of the study area is rather simple. It is made up of a series of alternating elongated ridges, hills and plateaus. The ridges consist of clayey sandstone rich with quartzite bedded on clay referred to as Numidian formations (Numidian aquifer) and Tellian carbonates bedded on marl (carbonate aquifer), (Vila, 1980; Chouabbi 1987). Structurally, the Numidian formations are carried on limestones and occupied the upper position. The aquifers are mainly recharged by precipitation; secondarily by the Infiltration of water from faults is another possible source of aquifers recharge.

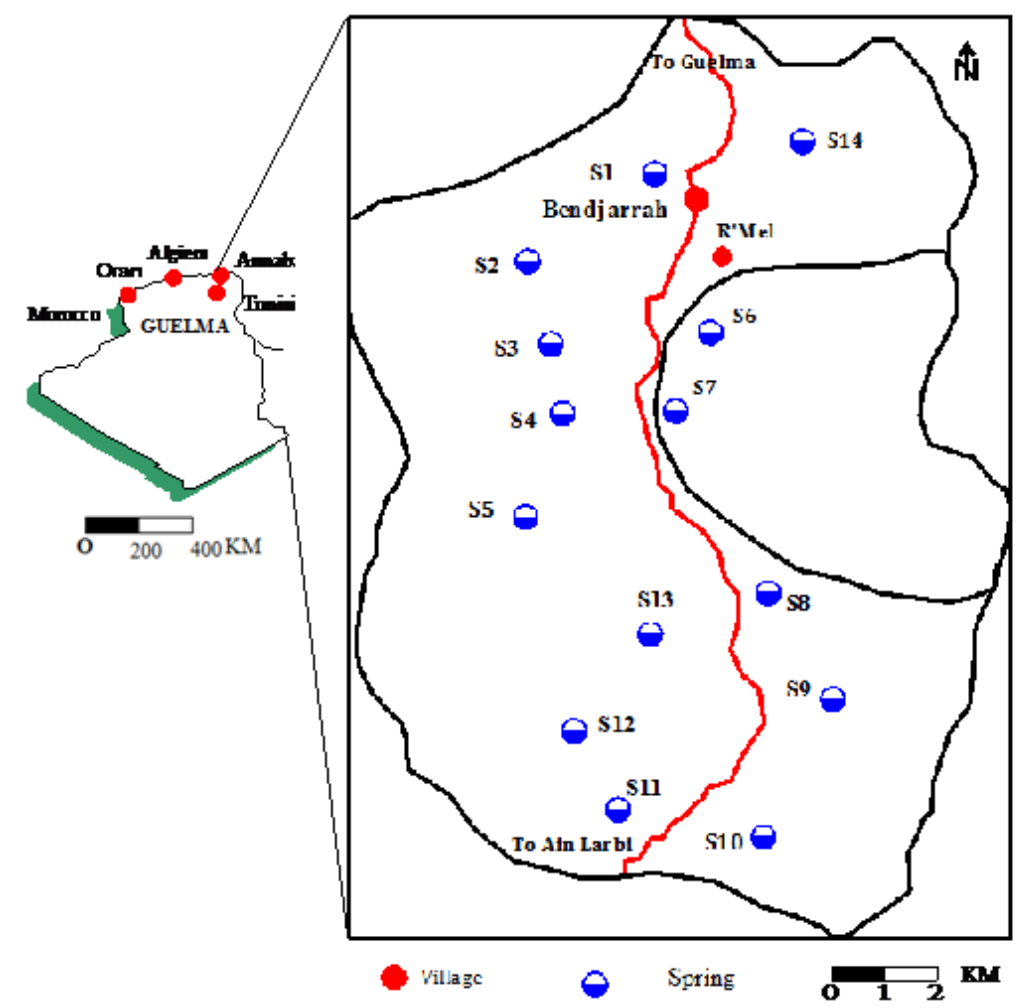

Fig 1:- Location of the study area in eastern part of Algeria

\section{Sampling analysis:-}

Ten major springs were assigned for sampling campaign (figure1). They were collected into new 1.1 polyethylene bottles that had been rinsed two or three times with the water to be analyzed. The bottles were filled until overflowing and closed underwater to minimize aeration. All bottles were carefully labeled and numbered prior to transport and kept at low temperature $4 \mathrm{C}$. Physico-chemical parameters (temperature, $\mathrm{pH}$, and EC) were measured in situ using a multi-parameter WTW, and dissolved oxygen was analyzed with device multiline P3PH/LF-SET with a selective probe (WTW). Alkalinity was determined using volumetric titration with sulfuric acid 50.1N-. The cations $\left(\mathrm{Na}^{+}\right.$and $\left.\mathrm{K}^{+}\right)$were carried up by flame spectrophotometric absorption. $\mathrm{Ca}$ and $\mathrm{TH}$ were determined by the titrimetry method using Eriochrome and Murexide as indicators. A spectrophotometer UV-visible spectral photolab WTW with compatible kits is used to analyze anions $\mathrm{Cl}^{-}, \mathrm{SO}^{2-}{ }_{4}, \mathrm{NO}_{3}^{-}$and metal $\left(\mathrm{Fe}^{3+}\right)$. Analyses have been accomplished at Civil Engineering and Hydraulic Laboratory m University of Guelma. The results of hydrochemical analysis were compared to WHO standards (2011) standards for the suitability evaluation of the water springs for drinking and domestic uses. To study the water quality for irrigation, sodium adsorption ratio (SAR), the percentage of sodium, and residual sodium carbonate (RSC), magnesium ratio, and Kelly's ratio were calculated. 


\section{Results and discussion:- \\ Water chemistry:-}

The samples were collected from 10 springs from the Mahouna Massif during the stage period (April 2016). The analytic results for each parameter and minimum, maximum, average and standard deviation are summarized in Tables 1 and 2.

Table 1: -Hydrochemical results of the springs

\begin{tabular}{|c|c|c|c|c|c|c|c|c|c|c|c|c|c|}
\hline ID & TDS & $\mathrm{pH}$ & $\mathrm{O} 2$ & $\mathrm{EC}$ & $\mathrm{Ca}^{2+}$ & $\mathrm{Mg}^{2+}$ & $\mathrm{Na}^{+}$ & $\mathrm{K}^{+}$ & $\mathrm{Fe}^{2+}$ & $\mathrm{Cl}^{+}$ & $\mathrm{SO}^{2-}$ & $\mathrm{NO}_{3}^{-}$ & $\mathrm{SiO}^{2}$ \\
\hline S1 & 668 & 7.65 & 6.10 & 1,120 & 56 & 12 & 154 & 6 & 6 & 225 & 86 & 4 & 13.25 \\
\hline S2 & 595 & 7.58 & 5.57 & 1,021 & 68 & 17 & 125 & 3 & 4.5 & 210 & 58 & 3.41 & 11 \\
\hline S3 & 595 & 7.42 & 5.29 & 848 & 87 & 36 & 48 & 2 & 2 & 100 & 50 & 10 & 6,25 \\
\hline S4 & 632 & 7.36 & 6.10 & 891 & 90 & 38 & 56 & 1.25 & 1.25 & 98 & 52 & 15 & 5.45 \\
\hline S5 & 624 & 7.60 & 5 & 1,061 & 65 & 15.60 & 136 & 5 & 3.20 & 215 & 48 & 21 & 8.98 \\
\hline S6 & 631 & 7.7 & 6.25 & 1,105 & 62 & 22 & 146 & 1.2 & 2 & 245 & 33 & 7 & 9.23 \\
\hline S7 & 654 & 7,72 & 5.32 & 1,129 & 53 & 12 & 163 & 4.25 & 1.32 & 256 & 36 & 9 & 12.02 \\
\hline S8 & 580 & 7.65 & 6.37 & 995 & 56 & 12 & 112 & 2 & 3.12 & 235 & 46.5 & 2 & 7.33 \\
\hline S9 & 610 & 7.73 & 6.15 & 1,061 & 60 & 13 & 145 & 3,2 & 3 & 228 & 39 & 10 & 5.66 \\
\hline S10 & 527 & 7.53 & 5.66 & 700 & 72 & 27 & 24 & 2 & 2.32 & 79 & 22 & 25 & 9.63 \\
\hline
\end{tabular}

Table 2:- Minimum maximum, averga and SD

\begin{tabular}{|c|c|c|c|c|}
\hline Variable & Minimum & Maximum & Mean & SD \\
\hline $\mathrm{TDS}$ & 558 & 664 & 613.30 & 32,79 \\
\hline $\mathrm{pH}$ & 7.36 & 7.73 & 7.59 & 0.13 \\
\hline $\mathrm{O} 2$ & 500 & 6.37 & 5.78 & 0.47 \\
\hline $\mathrm{EC}$ & 818 & 1.145 & $1,018.20$ & 120.23 \\
\hline $\mathrm{Ca}$ & 53 & 90 & 67.20 & 12.64 \\
\hline $\mathrm{Mg}$ & 12 & 38 & 21.26 & 9.65 \\
\hline $\mathrm{Na}$ & 48 & 163 & 114.30 & 44.03 \\
\hline $\mathrm{K}$ & 1.20 & 6 & 2.99 & 1.63 \\
\hline $\mathrm{Fe}$ & 1.25 & 6 & 2.87 & 72.46 \\
\hline $\mathrm{HCO}$ & 89 & 272 & 142.10 & 65.08 \\
\hline $\mathrm{Cl}$ & 98 & 256 & 191.00 & 14.87 \\
\hline $\mathrm{SO} 4$ & 33 & 86 & 49.65 & 7.60 \\
\hline $\mathrm{NO} 3$ & 2 & 25 & 10.64 & 2.70 \\
\hline $\mathrm{SiO} 2$ & 5.45 & 13.25 & 8.88 & \\
\hline
\end{tabular}

Waters samples in the study area are generally alkaline in nature with $\mathrm{pH}$ ranging from 7.36 to 7.73 with an average of 7.59 (Table 1). The waters samples are moderately oxygenated, with values oscillating between 5 and 6.37 . Electrical conductivity reflects the capacity of water to conduct electrical current, and is directly related to the concentration of salts dissolved in water. EC ranges from 818 to $1,145 \mu \mathrm{S} / \mathrm{cm}$ with an average of $1,018.20 \mu \mathrm{S} / \mathrm{cm}$. According to the analytical data, all the groundwater investigated can be classified into two groups. Group A, by far the most important one is representative of most springs witch emerge from Numidian sandstones. The second group comprises especially the water samples from the carbonate aquifer. (Fig.1). the first and the second group waters samples are low in mineralization. The total dissolved solids (TDS) vary from 558 to $664 \mathrm{mg} / \mathrm{l}$ (Table 1), the average value being of $613.30 \pm 32.78 \mathrm{mg} / \mathrm{l}$. Among the major cations (Fig. 3), a predominance of Na followed by $\mathrm{Ca}, \mathrm{Mg}$ and $\mathrm{K}$ is observed for the first group of groundwater. Concentrations of both $\mathrm{Na}^{+}$and $\mathrm{Ca}^{2+}$ (in $\mathrm{mg} / \mathrm{l}$ ) represent on average 36 and $33 \%$ of all the cations, respectively. $\mathrm{Mg}-\mathrm{K}$ ions are secondary in importance, representing on average $31 \%$ of all cations. Among the major anions (Fig. 3), $\mathrm{Cl}^{-}$generally dominates, representing on average $55 \%$ of all the anions followed by $\mathrm{HCO}^{-}$, however, the plot of some groundwater samples towards the Cl-NO3, and dominant field (Fig. 3) indicates that several springs contain groundwater with insignificant amounts of $\mathrm{NO}_{3}^{-}$(Table 1). $\mathrm{SO}_{4}^{2-}$ ions are less abundant; they represent on average 21 and $20 \%$ of all the anions, respectively. In contrast to this, the predominant anion trend is in the order $\mathrm{HCO}_{3}^{-}>\mathrm{Cl}^{-}>\mathrm{SO}_{4}^{2-}>\mathrm{NO}_{3}^{-}$in the spring $\mathrm{S} 5$ and S8 and in cations, the order is $\mathrm{Ca}^{2+}>\mathrm{Mg}^{2+}>\mathrm{Na}^{+}>\mathrm{K}^{+}$. The concentrations of dissolved silicate are heterogeneous, varying between 5.54 and $13.25 \mathrm{mg} / \mathrm{l}$. The average value is $8.88 \pm 2.70 \mathrm{mg} \mathrm{l}$. The second group groundwater show relatively low total dissolved solids (TDS) contents, with values ranging from 857 to $898 \mathrm{mg} \mathrm{l}^{-1}$, the average value being $613.30 \pm \mathrm{mg} / \mathrm{l}$. 


\section{Water-rock interaction processes:-}

Interactions between groundwater and surrounding host rocks are believed to be the main processes responsible for the observed chemical characteristics of groundwater in the study area. Evaluation of such processes requires the description of the main mineral assemblage of the rocks in which water is found, and the identification of chemical reactions responsible for the geochemical evolution of groundwater (Geroui et al, 2014, Rouabhia et al. 2010; Appelo and Postma,2005). From available studies in the literature, such reactions generally include chemical weathering of rock-forming minerals, dissolution-precipitation of secondary carbonates and ion exchange between water and clay minerals. In the present study, saturation indices (SI) with respect to carbonate (calcite, and dolomite), evaporate ( anhydrite and gypsum ), and siliceous (chalcedony ,quartz and amorphous silica), and minerals, as well as activities of soluble species, were calculated using the computer geochemical program PHREEQC and equilibrium partial pressure of $\mathrm{CO}$ 2. Saturation indices (SI) are listed in (Table 3), for anhydrite (CaSO4), gypsum $(\mathrm{CaSO} 4,2 \mathrm{H} 2 \mathrm{O})$, calcite $(\mathrm{CaCO})$, dolomite $\left(\mathrm{Ca}, \mathrm{Mg}\left(\mathrm{CO}_{3}\right)_{2}\right)$, chalcedony, quartz and amorphous silica and were calculated for 10 samples.

The saturation indices for anhydrite and gypsum is below zero in all samples, which means that water is under saturated with respect to anhydrite and gypsum. Saturation index for calcite ranges between -0.25 and 0.23 . 30\% of the sample have SI >0, which means that they are oversaturated for precipitation of calcite and $30 \%$ of the samples have SI $<0$ which means that they are under saturated with respect to calcite. For dolomite, Saturation index ranges between -2.2 and 1.9 , and $51 \%$ of the samples have SI>0, which means that they are oversaturated and precipitation of dolomite occurs. About $11 \%$ of the samples have SI $=0$, which means equilibrium conditions and $38 \%$ of the samples have SI $\backslash 0$, which means that they are undersaturated with respect to dolomite. All of the considered groundwater are saturated with respect to quartz and unsaturated with respect to chalcedony and to amorphous silica (table). The concentrations of dissolved $\mathrm{SiO} 2$ in water samples may thus be influenced by these siliceous All the Group A groundwater are under saturated with respect to calcite and dolomite (Fig. 5), suggesting that these carbonate mineral phases are absent in the corresponding host rock. In contrast, all the Group B groundwater are saturated with respect to calcite and dolomite indicating that these carbonate mineral phases may have influenced the chemical composition of this group of groundwater.

The distribution of the computed pCO2 values for all the measured groundwaters is illustrated in table 3 . For the studied period (May 2016), the calculated values appear to be considerably higher than atmospheric pressure $\left(10^{-3.5}\right.$ ) with values oscillating between $11.9610^{-3}$ to $1.9010^{-3} \mathrm{~atm}$. The elevated values can be explained that the aquifers system is opened to the soil $\mathrm{CO} 2$.

Table 3:- Saturation indexes and equilibrium partial pCO2 of water springs

\begin{tabular}{|c|c|c|c|c|c|c|c|c|c|}
\hline ID & Anhydrite & Calcite & Dolomite & Gypsum & Chalcedony & Quartz & SIO2(a) & Siderite & pCO2 $10^{-3} \mathrm{~atm}$ \\
\hline S1 & $-2,03$ & -0.23 & -0.86 & -1.79 & -0.03 & 0.41 & -0.9 & 1.02 & 2.17 \\
\hline S2 & $-2,1$ & -0.25 & -0.83 & -1.86 & -0.12 & 0.33 & -0.98 & 0.80 & 2.32 \\
\hline S3 & $-2,06$ & 0.16 & 0.22 & $-1,83$ & -0.37 & 0.07 & $-0,07$ & 0.69 & 9.56 \\
\hline S4 & $-2,04$ & 0.14 & 0.20 & -1.81 & -0.43 & $0 ., 01$ & -1.29 & 0.46 & 11.96 \\
\hline S5 & -2.21 & -0.19 & -0.73 & -1.97 & -0.21 & 0.24 & -1.07 & 0.73 & 2.52 \\
\hline S6 & -2.4 & -0.13 & -0.44 & -2.16 & -0.19 & 0.25 & $-1 ., 05$ & 0.61 & 1.94 \\
\hline S7 & $-2 ., 42$ & -0.16 & -0.7 & -2.18 & -0.08 & 0,37 & -0.94 & 0.46 & 1.89 \\
\hline S8 & -2.25 & -0.17 & -0.70 & -2.02 & -0.32 & 0.13 & -1.17 & 0.80 & 2.28 \\
\hline S9 & -2.31 & -0.06 & $-0,49$ & -2.08 & -0.43 & 0.01 & -1.28 & 0.86 & 1.90 \\
\hline S10 & -2.45 & 0.23 & 0.31 & -2.21 & -0.80 & 0.26 & -1.04 & 0.89 & 7.62 \\
\hline
\end{tabular}

\section{Drinking water quality:-}

The purpose of this section is to characterize the waters for both drinking as well as for irrigation purposes. Water was classified in Table 3 based on total hardness according to the classification of Sawyer and McCarty (1967).

Hardness is indicated from the presence of divalent metallic cations of which calcium and magnesium are the most abundant in groundwater. These ions react with soap to form precipitates. Hard water is unsatisfactory for household cleaning purposes, hence, water-softening processes for removal of hardness are needed (Todd 1980). Total hardness is calculated through the following formula:

$$
\mathrm{TH}=2.497 \mathrm{Ca}^{2+}(\mathrm{mg} / \mathrm{l})+4.115 \mathrm{Mg}^{2+}(\mathrm{mg} / \mathrm{l})
$$


It was observed that the examined water samples collected from springs were found to be hard, except the M2 which is located in the eastern part of the area studied. This water sample is classified as very hard water.

The calcium concentration is about $67.20 \pm 12.540 \mathrm{mg} / \mathrm{l}$. It is apparent that $\mathrm{S} 4$ showed higher calcium content compared to the other stations. WHO guidelines, 2011 did not specify a permissible limit for calcium in drinking water, but stated that calcium permissible limit in groundwater should be $75 \mathrm{mg} / \mathrm{l}$. according to the WHO (2011) guidelines; groundwater samples in the study area are acceptable for drinking purposes Except for S3 and S4 with 87 and 90mg/l respectively. Magnesium Concentration is $21.26 \pm 9.56 \mathrm{mg} / \mathrm{l}$. It is evident that the water samples had a magnesium concentration within the permissible limit of $100 \mathrm{mg} / \mathrm{l}$. Sodium can be tasted at concentrations of 200 $\mathrm{mg} / \mathrm{l}$ or more as stated in WHO guidelines for drinking water (WHO, 2011). When exceeding the limit, it gives salty taste together with the presence of chloride. The mean sodium concentration is $114 \pm 44.03 \mathrm{mg} / \mathrm{l}$. It is apparent that the water of the Mahouna massif showed generally sodium values within the permissible limit of $200 \mathrm{mg} / \mathrm{l}$. The mean potassium concentration is $2.99 \pm 1.63$ water indicates a low concentration of potassium $(\mathrm{max}=6 \mathrm{mg} / \mathrm{l})$ compared to the permissible limit of $10 \mathrm{mg} / \mathrm{l}$ (WHO, 2011). The mean ferrous iron $\left(\mathrm{Fe}^{2+}\right)$ value is $2.99 \pm 1.47 \mathrm{mg} / \mathrm{l}$, ferrous iron concentration is over the permissible limit of $1.0 \mathrm{mg} / \mathrm{l}$ (WHO,2011); groundwater samples in the study area are not acceptable for drinking purposes.

\section{Variation of anions:-}

The mean bicarbonate value is $191 \pm 65.08 \mathrm{mg} / \mathrm{l}$. Although, there are no exact permissible limits for bicarbonate in WHO guidelines (2011), the presence of HCO3- in drinking water should not exceed $500 \mathrm{mg} / \mathrm{l}$ in order to be safe for human consumption. HCO3- has a critical contribution to alkalinity of groundwater (Mohsin et al., 2013). The average chloride concentration in the Study area is $191 \pm 65.08 \mathrm{mg} / \mathrm{l}$ (station 6). High chloride values are recorded in the spring (S7) compared to the other stations where chloride values are below the permissible limit of $250 \mathrm{mg} / \mathrm{l}$. The mean sulfate concentration is $49.65 \pm 14.87 \mathrm{mg} / \mathrm{l})$ showing sulfate values or all springs under the permissible limit of $250 \mathrm{mg} / \mathrm{l}$. Nitrates in drinking water are a major contaminant in Algeria (Rouabhia et al. 2008; Fehdi, 2014). They are nowadays frequently found in aquifers. Nitrate (NO3-) concentrations of the waters samples (Table 1) were found far under the World Health Organization (WHO 2011) recommended limit (50 mg 1-1) especially for those samples occurring in Mountain areas. The mean nitrate concentration is $10.54 \pm 7.60 \mathrm{mg} / \mathrm{l}$. The waters samples showed nitrate values under the permissible limit of $50 \mathrm{mg} / \mathrm{l}$ (table1). The high concentration of nitrates in water samples are the result agricultural activity in the area.

\section{Suitability for irrigation:-}

In order to assess the groundwater f or irrigation practices, it should be analyzed using number of criteria. Water samples will be evaluated through four different methods. Soluble sodium percent (SSP), Sodium adsorption ratio (SAR) and Residual carbonate Sodium (RSC).

\section{Soluble sodium percent (SSP):-}

Soils containing a large proportion of sodium with carbonate as the predominant anion are termed alkali soils; those with chloride or sulfate as the predominant anion are saline soils, ordinarily, either type of sodium enriched soil will support little or no plant growth (Todd, 1980). Sodium content is usually expressed in terms of percent sodium defined by the equation:

$$
\mathrm{Na}^{+}(\%)=100 \cdot\left[\left(\mathrm{Na}^{+} /\left(\mathrm{Na}^{+}+\mathrm{Ca}^{2+}+\mathrm{Mg}^{2+}\right)\right]\right.
$$

Values relating to sodium percentage( table4), shows that most of the groundwater samples (80\%) fall in the category of excellent and $20 \%$ to Doubtful to unsuitable for irrigation purposes.

\section{Sodium Absorption Ratio (SAR):-}

Sodium is one of the most studied cations, because of its toxicity effects on crops and well-known effects on soil texture. High concentration of sodium disperses soil colloidal particles, causing the soil to be hard and resistant to water diffusion. The osmotic pressure in the soil then builds up and causes complications in water to be absorbed by plant roots (Richards, 1954). SAR is expressed as the formula (US Salinity Laboratory, 1954), where values of Na+, $\mathrm{Ca}+2, \mathrm{Mg}+2$ are in meq/l.

$$
S A R=N a^{+} / \sqrt{\mathrm{Ca}^{2+}+\mathrm{Mg}^{2+} / 2}
$$

The SAR value varies from 0.66 to 4.54 with an average of 2.87. All Samples are suitable for irrigation (Table 4)

\section{Residual Sodium Carbonate (RSC):-}

The high concentration of bicarbonate ions in water provokes the precipitation of $\mathrm{Ca}^{2+}$ and $\mathrm{Mg}^{2+}$ as carbonates and 
then the proportion of sodium in the soil increases. The RSC is calculated using the following equation:

$$
\mathrm{RSC}=(\mathrm{HCO}-3 \times 0,0333)\left(\mathrm{Ca}^{2+}+\mathrm{Mg}^{2+}\right)
$$

The concentration of $\mathrm{Ca}^{2+}$ and $\mathrm{Mg}^{2+}$ are in meq/l and alkalinity values in $\mathrm{mg} / \mathrm{l}$.

Irrigation water having RSC values greater than $5 \mathrm{meq} / \mathrm{l}$, have been considered harmful to the growth of plants, while waters with RSC values above $2.5 \mathrm{meq} / \mathrm{l}$ are unsuitable for irrigation. An RSC value between 1.25 and 2.5 $\mathrm{meq} / \mathrm{l}$ is considered as the marginal quality and value $<1.25 \mathrm{meq} / \mathrm{l}$ as the safe limit for irrigation (Richards 1954). The calculated RSC values in the groundwater samples of Bouchegouf aquifer are found to vary from -3,85to 1.14 meq/l with an average of -1.38 meq/l (Table 4). Regarding to the RSC values, all samples are suitable for agricultural purposes.

Table 4. -Results of the calculations of SAR, SSP and RSC

\begin{tabular}{|c|c|c|c|}
\hline ID & SAR & SSP $(\%)$ & RSC \\
\hline S1 & 4.54 & 54.08 & 8.17 \\
\hline S2 33 & 3.59 & 51.68 & 7.77 \\
\hline S4 & 1.42 & 31.40 & 13.06 \\
\hline S5 & 1.28 & 24.53 & 7.91 \\
\hline S6 & 3.98 & 56.24 & 8.19 \\
\hline S7 & 1.07 & 56.48 & 6.98 \\
\hline S9 & 4.07 & 66.57 & 7.13 \\
\hline S10 & 3.61 & 56.57 & 7.41 \\
\hline Mean & 4.53 & 62.89 & 14.44 \\
\hline
\end{tabular}

\section{Conclusion:-}

This study has thrown light on hydrochemical quality of springs in Mahouna Massif, as well as on the status of the water quality in the study area. Physicochemical parameters showed that the waters springs are suited for drinking and domestic uses due to low amounts of cations and anions, except for calcium witch preset an amount over the permissible limit of WHO. According to SAR, SSP and RSC water samples are suitable for irrigation uses.

\section{References:-}

1. Appelo, C., ,Williemsen, A. (1987). Geochemical calculations and observations on salt water intrusions, I: a combined geochemical mixing cell model. J Hydrol 94: 313-330.

2. Chouabbi, A. (1987). Geological study of the Hammam N'bails area (SE Guelma, Constantine region, Algeria), PhD Thesis, University Paul Sabatier in Toulouse, p123.

3. Fehdi, C. et al., (2016). Hydrochemical and microbiological quality of groundwater in the Merdja area, Tebessa, North-East of Algeria. App Water sci 6:47-55.

4. Geroui, Y. et al., (2014). Hydrochemical and bacteriological investigation in groundwater of the Tamlouka Plain, north-east of Algeria. Arab J Geosci DOI 10.1007/s12517-014-1393.

5. Mohsin et al., (2013). Assessment of drinking water quality and its impact on residents' health in Bahawalpur City. International Journal of Humanities and Social Science, 3(15), 114-128.

6. Richards, L.A. (1954). Diagnosis and improvement of saline and alkaline soils. U.S. department of Agriculture Hand Book.

7. Rouabhia, A. et al..(2008a). Impact of human activities on quality and geochemistry of groundwater in the Merdja area, Tebessa, Alegria. Environ Geol. doi:10.1007/s00254-008-1225-0.

8. Rouabhia, A, Baali, F. Fehd,i C. (2010). Impact of agricultural activity and lithology on groundwater quality in the Merdja area, Tebessa, Algeria. Arab J Geosci 3:307-318.

9. Sawyer, G.N. . McCarty, D.L. (1967). Chemistry of sanitary engineers, $2^{\text {nd }}$ edn. McGraw Hill, New York.

10. Todd, K. (1980). Groundwater hydrology, 2nd edn. Wiley, New York, p 510.

11. Vila, J .M. (1980). La chaîne alpine d'Algérie orientale et des confins Algéro-Tunisiens. PhD of Science, University Pierre et Marie Curie, Paris V.

12. Wilcox L.V. (1948). The quality of water for agricultural use. US Dept Agriculture Tech Bull 962, Washington

13. WHO, (2011). World Health Organization. (2011). Guidelines for drinking water quality. Fourth Edition. WHO Library Cataloguing -in-Publication Data. Geneva. 